\title{
Sudan: Fredsaftale på viagra og petro-yuan
}

\section{Nils Carstensen}

\section{Darfur forværres den humanitære situation uden udsigt til en snarlig løsning. I Khartoum overskygger hæmningsløs økonomisk optimisme alverdens kritik og skepsis}

Den sudanesiske fredsaftale fra 5. januar 2005 var rig på erklæringer om folkeafstemning, demokratiske valg, velstandsdeling og respekt for menneskerettigheder. Godt to år senere har virkelighedernes verden omformet de smukke erklæring til et $\mathrm{Su}$ dan, der kort kunne sammenfattes som: Etnisk fordrivelse og massive krigsforbrydelser i Darfur, en styrkelse af de totalitære kræfter i det nordlige Sudan og en langvarig magtkamp blandt lederne i syd, der har efterladt de tidligere oprørere noget nær handlingslammede.

Korruption og magtmisbrug er allestedsnærværende og måske i realiteten det, der nu holder sammen på den samlingsregering, der var et resultat af fredsaftalen mellem regeringen i Khartoum og oprørerne i det sydlige Sudan.

Dystre meldinger fra Afrikas stør- ste land? Nej egentlig ikke - for hele balladen opvejes af, at pengene strømmer ind fra en voksende oliesektor og afledte serviceindustrier. Med en stigning i bruttonationalproduktet på anslået 13 pct. sidste år og en stålsat politisk og økonomisk partner i den kinesiske regering, er det svært at finde grund til pessimisme hos den politiske og $\varnothing$ konomiske elite i nord.

Eller for den sags skyld blandt den 'nye' elite i syden, der hastigt er vokset frem blandt de sydsudanesere, der i kraft af familietilhørsforhold og deres 'bedrifter' under krigen nu så rigeligt tager for sig af den 'fredsdividende', som fredsaftalen udløste til de heldige få.

Hvad gør det egentlig, at der stadig ikke er kommet skoler, sundhedsklinikker og veje ud til landsbyerne, så længe huspriserne i både 
Khartoum og den sydlige hovedby Juba fortsætter deres himmelflugt?

Hvad gør det, at de tidligere oprøreres medlemmer i samlingsregeringen i Khartoum ingen indflydelse har i de ministerier, de er ministre for, så længe de kan sætte lidt til side til sig selv og så i øvrigt feste godt og grundigt igennem som en velfortjent kompensation for 'de tyve tabte år i bushen'?

Hvor meget politisk analyse af magtforholdet mellem de to regeringspartnere har man brug for, når man kan notere sig, at det sidste år lykkedes et meget centralt placeret sydsudanesisk regeringsmedlem at blive akut indlagt på militærhospitalet i Khartoum i et koma udløst af vedvarende overdreven indtagelse af viagra og sprut?

For resten af befolkningen gælder sharia stadig i det nordlige Sudan, men den viagra-med-mere-hungrende minister bestrider selvsagt stadig sit embede (på sine gode dage) og nyder de dertilhørende goder (resten af tiden).

I bund og grund; hvorfor bekymre sig om, at fredsaftalen efter to år holder sig oppe på viagra, så længe man stadig kan hænge sit fint pressede jakkesæt eller nye jalabya på den?

Og hvorfor bekymre sig om, at vestlige ledere, velmenende pop- og filmstjerner sammen med hjælpeorganisationerne råber op om et påstået folkemord ude i Darfur, så længe man kan stave til to små ord på hver fire bogstaver: Kina og olie.

\section{Ny verdens-u-orden}

På en stille eftermiddag ved Nilpromenaden i Khartoum forfalder man let til at kigge på byen, som den spejler sig i den Blå Nils grumsede vandmasser. Spejlbilleder, der i disse måneder er under voldsom forandring i takt med at asiatiske og mellemøstlige investorer sammen med sudanesiske forretningsfolk og regeringsinteresser har startet et forrygende kapløb om at bygge de største, højeste og mest prangende projekter. Hoteller, kontor- og konferencekomplekser, golfbaner, broer - you name it. Afrikas 'Dubai' ligger parat på tegnebordene og er nu ved at rejse sig ud af det hidtil så søvnige og tilsandede Khartoum.

Trods vestlige handelsrestriktioner og sanktioner bliver troen på fortsat økonomisk vækst støbt i jernbeton hver eneste dag.

Et par hundrede kilometer nordpå langs Nilens løb mod Egypten er et kæmpe dæmningsprojekt under opførsel af kinesiske entreprenører, men finansieret af arabiske banker og fonde.

Elektricitetsværkerne, der er planlagt her, skal sikre billig strøm til millioner af airconditionanlæg længe efter at olie-boom'et formodentlig tørrer op inden for et årti eller to. At en god del af Sudans nubiskkushitiske fortid i samme håndbevægelse bliver begravet på dybt vand, bekymrer ikke nogen nævneværdigt. 
Og mens vestlige hjælpearbejdere på vej til Darfur pænt kan vente en times tid ved paskontrollen i lufthavnen, skovles kinesiske gæstearbejdere igennem en 'fast track procedure', der er væsentlig mere effektiv end de særlige 'EU nationals'-køer i Frankfurt og andre europæiske lufthavne.

Kilderne til og aktørerne i det nordlige Sudans økonomiske boom er mangfoldige, men motoren og det strategisk afgørende omdrejningspunkt er til at få øje på - nemlig det kinesiske engagement i den sudanesiske olieindustri og den internationale politiske 'immunitet', som kineserne i realiteten har givet Sudans ledere.

Kinas nationale olieselskab er Sudans vigtigste økonomiske partner i olieudvinding og en fifty-fifty partner i den olierørledning, der forbinder oliefelterne i syden med Port Sudan ud til det Røde Hav. Olien fra Sudan udgør knap 10 pct. af Kinas nuværende olieimport, og den andel ventes at stige. Så selvom Sudan ikke bliver en eksportør på linje med Nigeria eller Angola, er 10 pct. vigtig for en kinesisk økonomi i femte gear. Og selv om den sudanesiske olieproduktion ventes at forblive beskeden i en global sammenhæng, er betydningen for den lokale økonomi - og derfor også de politiske magtforhold - kolossal.

Men vigtigere end detaljerne i de kinesisk-sudanesiske relationer er måske det kig til en ny verdens-u-or- den, man nu kan skimte i spejlingerne af Sudans nye vækstsymboler langs Nilen.

Da Kinas præsident Hu Jintao besøgte Sudan i februar, var det et foreløbigt højdepunkt for et samarbejde, der har udviklet sig over de seneste godt ti år og hjulpet Sudans islamistiske regime ud af noget nær komplet politisk isolation og økonomisk stagnation.

Da præsident $\mathrm{Hu}$ Jintao fløj ud af Khartoum lufthavn, efterlod han ikke blot sin underskrift på flere nye samarbejdsprojekter, en symbolsk donation til uddannelse af unge sudanesere og et løfte om at finansiere et nyt præsidentpalads til Omar el Beshir. Hu Jintao tog også noget med sig til brug på sin videre færd rundt til syv øvrige hovedstæder i Afrika: Et lyslevende eksempel på, at selv hvor vestlige lande med USA i spidsen forsøger at tvinge sin vilje igennem, kan Kina tilbyde et 'rentefrit' alternativ, der oven i købet virker. Økonomisk samarbejde, arbejdspladser og udviklingsprojekter uden andre betingelser, end at det skal kunne betale sig for Kina.

Hvor USA og europæiske regeringer forlanger demokrati, god regeringsførelse og respekt for menneskerettigheder i bytte for udviklingsprojekter af tvivlsom nytteværdi på den korte bane, tilbyder Kina rentefri lån til et nyt palads i dag, nye arbejdspladser i morgen og politisk 'beskyttelse' helt ind på de permanent pladser i FN's Sikkerhedsråd - 
også selvom du har et halvt folkemord kørende i din baghave.

Man behøver ikke at have studeret særlig længe på Statskundskab for at se, hvad der umiddelbart virker mest tillokkende for mangen en hårdt trængt afrikansk leder. Eller for at forstå, at den vestlige indflydelse i visse dele af Afrika falmer hastigt i disse måneder og år. $\mathrm{Og}$ med dén vakler i øvrigt også de vestligt dominerede hjælpeorganisationernes fodfæste på kontinentet. Det har de dog selv langtfra forstået endnu, om end udviklingen i Darfur taler sit eget tydelige sprog.

\section{En weekend i Darfur}

Knap fire år efter at en lille gruppe oprørere gennemførte et overraskelsesangreb på de sudanesiske regeringsstyrker i El Fasher, er Darfur sunket ned i et menneskeligt helvede og en politisk og militær situation så kompleks, at ingen med rette kan påstå, at de kan udrede den.

I sådan en situation kan det være sundt at lade fakta tale for sig selv, så nedenfor følger nogle korte klip fra FN's sikkerhedsbrief for Darfur over en weekend midt i februar:

Angreb: Shangil Tobayi, syd for el Fasher: Tre bevæbnede mænd på kameler åbnede kl. 19.00 ild mod en lille styrke regeringssoldater der skød igen med maskingeværer og morterer. Angriberne blev tvunget til at trække sig tilbage.

Skyderi: Tine, nordvest for Kutum: En patrulje fra den Afrikanske Union (AMIS), der ledsagede en officer fra regeringshæren, og en lokal sultan blev uden varsel beskudt af regeringssoldater i udkanten af Tine. AMIS skød igen, og en 30 minutter lang skudveksling fulgte. Til sidst lykkedes det officeren fra regeringshæren at kontakte sine kolleger og få dem til at indstille skyderiet.

Angreb: Um Baru n.v. for Kutum: Regeringsstyrker og oprørsstyrker (der har underskrevet "Darfur Fredsaftalen”) udkæmpede et længere slag ved Orshi. Der rapporteres om mange sårede og dræbte.

Skyderi: El Fasher: Ca. kl. 21.00 udbrød der heftigt skyderi i den vestlige del af byen. Siden viste det sig, at det var en del af en bryllupsfest, der har stået på siden sidste uge.

Baghold: Bulbul, s.v. for Nyala: Kl. ca. 13.00 blev en konvoj fra regeringshæren angrebet af arabiske militser. En officer og tre soldater blev sårede under ildkampen, men konvojen undslap bagholdet. Senere blev en angrebshelikopter set i luften over området. Konvojen var på vej til et forsoningsmøde mellem guvernøren og lokale arabiske stammer.

Baghold: Garsilla s. for Zalingei: Kl. 13.35 beskød et ukendt antal arabiske nomader to ngo-køretøjer ved Um Kher. Den forreste bil blev ramt af 11 skud og fik forruden smadret, men køretøjet undslap. Den anden bil blev også beskudt og en jordemor blev ramt i låret. Bilen undslap og den sårede kvinde blev kørt til 
klinikken i Um Kehr og siden til hospitalet i Nyala.

Overfald: Zalingei: Om eftermiddagen gik en mindre gruppe kvinder fra Hassa Hissa lejren ud for at samle brænde. Uden for lejren blev de antastet af tre bevæbnede nomader. En kvinde blev bortført og seksuelt mishandlet, mens de øvrige stak af.

Ueksploderet ammunition (UXO): Zalingei: $\mathrm{Ca}$. kl 15.40 snublede to piger på henholdsvis 14 og 9 år over en UXO. Den eksploderede og dræbte den 14-årige pige på stedet og sårede den 9-årige. Hun blev straks bragt på hospitalet af soldater fra nærliggende garnison, hvor hun blev behandlet og senere udskrevet. Den døde piges højre arm og ben var revet af og hendes krop var gennemhullet af metalstykker.

Røveri, El Geneina: Om natten brød bevæbnede røvere ind i finansministeriets kontor og stjal ca. to mio. sudanesiske dinarer (ca. 100.000 DKK) til lønudbetalinger den følgende dag. Godt 150 ansatte blev dagen efter afhørt af politiet, men yderligere oplysninger er ikke tilgængelige.

"Welcome to my world" - kunne man fristes til at sige. Tre års intens diplomatisk aktivitet og mindst syv resolutioner fra FN's Sikkerhedsråd senere, er det indlysende, at omverdenen ikke har formået at hjælpe parterne i Darfur med at løse konflikten(-erne) og endnu mindre formået at håndhæve bare et minimalt krav om beskyttelse af civilbefolkningen og hjælpearbejderne.
På den anden side af Sudans vestlige grænse er både Chad og den Central Afrikanske Republik blevet suget ind i den syndflod af etnisk vold og politisk fragmentering, der udgår fra Darfur og mere eller mindre åbenlyst stimuleres fra Khartoum.

\section{Tålmodighed en dyd}

FN's nye generalsekretær har ved flere lejligheder sagt, at konflikten i Darfur er en af hans første prioriteter, og han havde da også et direkte møde med den sudanesiske præsident Omar el Beshir i slutningen af januar. I centrum for deres diskussion stod indsættelsen af FN-forstærkninger til den forkrøblede AU-mission i Darfur. Forstærkninger som FN's Sikkerhedsråd vedtog tilbage i 2006, men som stadig afvises af Omar el Beshirs regering.

"Vi må udvise tålmodighed i vores opfølgning på denne politiske proces og på fredsprocessen", udtalte Ban Ki-Moon efter sit halvanden time lange møde med Omar el Beshir.

FN's tidligere særlige udsending til Sudan, hollænderen Jan Pronk, var en kende mere direkte i sin analyse af FN's rolle i et interview med Sudan Tribune midt i februar.

"Jeg gik i brechen for mine ansatte i Sudan og jeg forsvarede dem, mens jeg var der. Den nuværende ledelse af FN-missionen i Sudan er hovedløs og håndterer blot de admini- 
strative aspekter af aftalerne. Og de har ingen opbakning fra New York."

Omar el Beshirs regering smed Jan Pronk ud af Sudan i november sidste år, efter at Pronk have skrevet og talt om det sudanesiske militærs nederlag i et par større slag i Darfur. FN gjorde aldrig noget helhjertet forsøg på at få ham tilbage ind i Sudan.

Midt i februar så det se ud som om, at hvedebrødsdagene mellem Ban Ki-Mon og Omar el Beshir ville blive korte, da Sudan i ugevis blokerede et besøg af FN's menneskerettighedseksperter til Darfur. "Jeg er meget skuffet," sagde Generalsekretæren ved den lejlighed.

Et par dage senere kvitterede Omar el Beshir ved at kalde den FNstyrke, som Sikkerhedsrådet autoriserede i 2006, for en "besættelsesstyrke på linje med den amerikanske invasion af Irak.”

\section{Et halvt folkemord senere}

Godt og vel tre år og et halvt folkemord inde i konflikten i Darfur er bundlinjen til at få øje på. Uden en troværdig militær trussel mod Khartoum vil regimet ikke lade en vestlig alliance anført af USA og dele af EU diktere, hvordan den håndterer konflikten i Darfur.

En omsiggribende international 'Forsvar Darfur' bevægelse og 'dybt bekymrede' regeringer som den danske har i realiteten kun tre kort tilbage på hånden.
- Den Internationale Domstol i den Haag har annonceret, at den vil offentliggøre de første sigtelser og arrestordrer i forbindelse med deres undersøgelser af krigsforbrydelser i Darfur.

- Den amerikanske regering og en række EU-medlemmer truer med at gennemføre en række økonomiske sanktioner rettet mod den sudanesiske regering og enkeltpersoner med særligt ansvar for begivenhederne i Darfur.

- Man kan fortsætte med at tigge eller true den kinesiske regering til at gøre deres indflydelse i Khartoum gældende og udvirke, at Sudan accepterer bl.a. en udvidet AU-FN-mission i Darfur (med en betragtelig kinesisk komponent?).

Ingen af de tre 'kort' virker overbevisende. Sudan anerkender ikke retten i Haag og vil aldrig udlevere de sigtede til retsforfølgelse. Den sudanesiske økonomi er overvejende rettet mod Asien og Mellemøsten, så økonomiske sanktioner vil formodentlig kun blive irriterende for regimet i Khartoum. Men uden deltagelse af toneangivende samhandelspartnere som Kina, Indien og SaudiArabien vil de ikke blive økonomisk afgørende.

Kina har selvsagt megen ringe $\varnothing$ konomisk eller politisk interesse i at bruge deres indflydelse til at tvinge FN's resolutioner igennem for Darfur. Tænk olieforsyningssikkerhed. Tænk Tibet.

For befolkningen i Darfur er der 
derfor større håb knyttet til en gryende forsoningsproces mellem de rivaliserende oprørsgrupper. Sådan en forsoning er et første skridt hen mod en senere fælles forhandling med Omar el Beshirs regering og dens allierede militser.

Khartoum gør i disse uger og måneder, hvad den kan for at bombe og forfølge oprørslederne, hver gang de forsøger at mødes, men viljen til at gøre fællesfront er til stede blandt flertallet af oprørslederne og en lille gruppe sudanesiske intellektuelle arbejder hårdt bag kulisserne for at få det til at ske.

Det eneste lille problem med den løsning er, at den kommer til at tage måneder, hvis ikke år, og en effektiv våbenhvile er en akut humanitær nødvendighed i Darfur.

I det sydlige Sudan tog en lignende intern forsoningsproces mellem rivaliserende oprørsgrupper ca. 10 år, men den var en afgørende forudsætning for de efterfølgende egentlige fredsforhandlinger, der førte til afslutningen af over 20 års borgerkrig mellem nord og syd i 2005.

\section{Under Salva Kiirs hat}

Fredsaftalen mellem nord og syd var kun et halvt år gammel, da oprørsbevægelsen Sudan People's Liberation Armys (SPLA) leder, John Garang de Mabior, døde i et helikopterstyrt i det sydlige Sudan.

I al hast blev hans næstkommanderende gennem det meste af kri- gen, Salva Kiir Mayardit, udnævnt som leder af SPLA, og et sammenbrud for fredsaftalen blev undgået på et hængende hår. Salva Kiir er siden blevet mere kendt for den bredskyggede hat, han bestandigt bærer, end for en klar politisk vision for det SPLA, der nu har regeringsansvar både som delstatsregering for syden og som 'junior partner' i en national samlingsregering i Khartoum.

Kritikken af Salva Kiir for hans mangel på en national vision er korrekt af den simple grund, at sådan en vision har aldrig været en del af hans tænkning. For ham - og formodentlig det store flertal af sydsudanesere - er planen blot at træde vande på alle nationale emner frem til 2011. Da skal det sydlige Sudan ifølge fredsaftalen gennemføre en internationalt overvåget folkeafstemning om, hvorvidt regionen ønsker selvstændighed eller vil vedblive at være en del af et samlet Sudan.

Salva Kiir synes ikke at være et sekund i tvivl om, hvad udfaldet af den afstemning vil blive: Et selvstændigt Sydsudan. Det er i det perspektiv, man må forstå Salva Kiir og store dele af SPLM's (der nu har skiftet A'et ud med et $\mathrm{M}$ for Movement) absolutte fravær, når nationale emner er på bordet i både parlament og kabinetsmøder. Fx støtter SPLM ikke den 'nationale' regerings overgreb i Darfur, men vil samtidig ikke risikere så meget som en tomme af 'deres' fredsaftale for at komme Darfur til undsætning. 
At den fortsatte konflikt i Darfur så i stigende grad er ved at undergrave nord/syd-aftalen, er tilsyneladende ikke feset ind under Salva Kiirs hat. Eller også har han blot erkendt sin totale magtesløshed i forhold til et emne, som 'storebror' i National Congress Party (NCP - en del af det gamle NIF - National Islamic Front) i Khartoum tydeligvis skalter og valter med præcis, som det passer dem. Politiken og direktiverne til fx forsvars- og udenrigsministerierne for Darfur fastlægges på hemmelige møder i NCP-toppen ikke på kabinetsmøderne nede i det gamle præsidentpalads ved Nilen. Et faktum som Salva Kiir og hans SPLMrepræsentanter i samlingsregeringen aldrig for alvor har bestridt. Darfur er det internationale samfunds problem - ikke SPLM's.

\section{Etnisk kabale}

Hvor kynisk SPLM's holdning til konflikten i Darfur end kan forekomme, afspejler den tre forhold, der er afgørende for SPLM og Salva Kiir. Bevægelsen er internt splittet, den står i problemer til halsen som ledere og administratorer i syden og den er reelt magtesløs i forholdet til National Congres Party i alle afgørende nationale spørgsmål.

Mens ingen for alvor truer Salva Kiir som leder af SPLM og dermed automatisk Sudans nominelle vicepræsident og præsident for de sydlige delstater, er der konstant kamp om stort set alle andre magtpositioner, der besættes af SPLM.

Da den tidligere oprørsbevægelse i løbet af 2005 skulle udfylde sine poster i samlingsregeringen i Khartoum og - samtidig - etablere en politisk og administrativ ledelse for det sydlige Sudan, fulgte SPLM en hæderkronet tradition fra det fleste andre sejrrige oprørsbevægelser. Alle vigtige poster blev, med meget få undtagelser, besat uden smålig skelen til professionelle kvalifikationer, men med al mulig hensyn til to andre forhold. Loyalitet og politiske og militære bedrifter under krigen var det ene hensyn. Det andet var at komme op med en kabale, der kunne pacificere væsentlige dele af Sydsudans meget sammensatte etniske landskab.

Med mere end 100 forskellige stammer er den kabale en gyser af dimensioner og nok til i sig selv at forklare Salva Kiirs konstante fravær fra den nationale politik i Khartoum. At holde sammen på sydens rivaliserende stammer og grupperinger kræver sin mand. At det faktisk i det store og hele er lykkedes, er nok Salva Kiirs største politiske bedrift. Og i øvrigt en bedrift som afdøde John Garang måske ikke havde mestret med sin mere diktatoriske og uforsonlige stil.

En del af prisen for at holde alle stammer nogenlunde tilfredse har været en inkompetent politisk og administrativ ledelse, der ikke formår at 'levere varen' i form af sko- 
ler, sundhedsklinikker, veje osv. ude på landet. Hvad denne nye elite derimod har været dygtige til, har været at hytte deres eget og deres umiddelbare families skind. Et faktum der ikke er gået upåagtet hen hos en ludfattig lokal befolkning.

\section{0 mio. dollars}

I anledning af toårs-dagen for underskrivelsen af fredsaftalen, besøgte Omar el Beshir den sydsudanesiske hovedstad Juba, hvor han og Salva Kiir talte til tusinder af forsamlede sydsudanesere. Til Beshirs synlige irritation kastede Salva Kiir sig ud i et totalangreb på el Beshir og NCP for på alle måder at forsinke og forhale gennemførelsen af fredsaftalen. Jublen blandt Salva Kiirs hjemmebane-publikum var betragteligt.

Da Salva Kiir var færdig, overtog Omar el Beshir mikrofonen. Beshir lod sin forberedte tale ligge på stolen bag sig og kastede sig ud i et improviseret modangreb. Knock outstødet kom, da Beshir bad Salva Kiir forklare, hvad der var blevet af de 60 millioner dollars, som han overførte til Garang og SPLA kort efter, at fredsaftalen blev skrevet under i januar 2005. Pengene skulle gøre det muligt for SPLA at sende en delegation til Khartoum for at sætte fart i gennemførelsen af fredsaftalen. Beshirs bemærkninger skabte stilhed på de billige rækker i Juba, og selv ikke Salva Kiirs hatteskygge var bred nok til at skjule ubehaget.
Det er en offentlig hemmelighed, at en betragtelig del af de 60 mio. dollars blev fløjet i kontanter direkte til SPLA/M's kontor i Rumbek. Her blev de i de sene nattetimer delt ud til højtstående Commandere og andre støtter, der havde bakket op om Garang og hans del af SPLA/M gennem krigen. Så vidt vides, blev der ikke bedt om kvitteringer ved den lejlighed.

Siden dengang i det tidlige 2005 er pengeoverførslerne fra Khartoum til syden, og den af SPLM udnævnte kassemester, vokset mange, mange gange. Men de kigger stadig langt efter skolerne, klinikkerne og vejene i de fleste landsbyer spredt ud over syden.

Hvis SPLM og Salva Kiir skal overleve de valg, der er planlagt til 2008, er det ikke en løsning for Darfur, der kan redde dem. Det er derimod de ting, de i praksis kan nå at udrette for udviklingen i det sydlige Sudan. Ikke flere handlingsplaner og visioner - folket vil have mursten, malariamedicin og asfalt. Og en oprydning blandt de meste korrupte elementer af den nye 'elite' i syden.

Derfor er Salva Kiir en sjælden gæst i Khartoum. Derfor har han og SPLM ikke spillet noget rolle i forhold til Darfur eller andre afgørende nationale emner. $O g$ på den måde har Omar el Beshir og den øvrige inderkreds i NCP i virkeligheden fået det bedste af to verdener: En fredsaftale, de kun delvis behøver at leve op til, og en samlings- 
regering med det afrikanske og til dels kristne SPLM, der dæmmer godt op for udlandets værste kritik. Samtidig har NCP i realiteten fastholdt den fulde frihed til at gennemføre en opdateret version af den politik, de har stået for, siden de tog magten ved et militærkup i 1989.

\section{Sharia i $4 \times 4$ drive}

Som i de tidlige 1990'ere bygger NCP's politik på islam og sharia som det centrale værdi-sæt. Men Omar el Beshirs NCP har siden 1995 bl.a. skiftet gamle allierede som Osama Bin Laden og Carlos the Jacqal ud med de kinesiske og indiske nationale olieselskaber.

Det gamle, hårdkogte National Islamic Front fremstår nu som et slags skabskapitalistisk, islamisk velfærdsparti. Dog uden vestlige tåbeligheder som demokrati, ytringsfrihed og menneskerettigheder - men nu med split unit-aircons og Toyata 4X4's til folket (i velhaverkvarterene i Khartoum).

Skift farven grøn ud med rød. Skift islam ud med det kinesiske kommunistparti. Og gør så selv regnestykket op - uden dog at trække parallellerne alt for langt.

Set fra Khartoum er NCP's transformation over de sidste 10 år rent ud sagt genial - og politisk meget, meget dygtigt spillet af et regime, der i midten af 1990'erne balancerede på randen af politisk og økono- misk kollaps både nationalt og internationalt.

Sudan, og Khartoum i særdeleshed, er ikke bare der, hvor den Blå og den Hvide Nil løber sammen. Det er også der, hvor Afrika møder Arabien, og hvor NCP's ledelse dagligt beviser, at de faktisk kan både blæse og have mel i munden. Et halvt folkemord i baghaven, en fredsaftale på druktur og viagra, tusinder der dør af underernæring hver måned - og en økonomisk vækst på 13 pct. om året.

Gængs politisk analyse har altid haft det svært i Sudan. Her kommer alligevel et gæt om det kommende års tid: Vandet vil blive ved med at løbe op ad Nilen; NCP vil fastholde sit greb om magten i Khartoum; FN får ikke sin egen styrke ind i Darfur; fredsaftalen mellem nord og syd vil ikke bryde officielt sammen, så længe der er penge nok til 'smørelse'; men aftalen vil gradvis blive mere og mere indholdsløs - og dén med folkeafstemningen om selvstændighed for Syden i 2011 - tjah... In shallah!

Men mon ikke strategerne i NCP og deres udenlandske forretningspartnere har en plan, der tager højde for det kapitel også. En plan der indbefatter de penge, der allerede tikker diskret ind på udvalgte sydsudanesiske lederes private bankkonti i udlandet.

Nils Carstensen er journalist og forfatter, bosat $i$ Khartoum. 